Jurnal Administrasi Publik (Public Administration Journal), 10(2) December 2020

ISSN2088-527X (Print) ISSN2548-7787 (Online) DOI: https://doi.org/10.31289/iap.v10i2.3622

Jurnal Administrasi Publik (Public Administration Journal)

Available online http://ojs.uma.ac.id/index.php/iap

\title{
Policy Networks in the Implementation of 'Cities Without Slums' Program in Baleendah District, Bandung Regency
}

\author{
Ahmad Hadi*, Budiman Rusli \& M. Benny Alexandri \\ Master of Public Policy, Faculty of Social and Political Sciences, Padjadjaran University, \\ Indonesia
}

Received: March 22, 2020; Reviewed: May 05, 2020; Accepted: July 22, 2020

*Coresponding Email: ahmadhadinasri@gmail.com

\begin{abstract}
This study is entitled Policy Network in the Implementation of 'Cities Without Slums' Program (KOTAKU) in Baleendah District, Bandung Regency. This study is motivated by the author's interest in the implementation of the KOTAKU program, which is a collaborative platform program but in its implementation there are still problems related to coordination and participation in achieving the goals of 'cities without slums' program. This study used descriptive research method with a qualitative approach, and the results of studywere obtained from library research and field studies, namely observation, documentation, and interviews. This study used the Deleon and Varda policy network theory which consists of several characteristics: representation, reciprocity, horizontal power structure, embeddedness, trust and formality, participatory decision making, and collaborative leadership. Based on the results of this study, it can be concluded that the Policy Network in the Implementation of the KOTAKU Program in Baleendah District, Bandung Regency is not optimal because some of the characteristics that exist in the policy network are representation, horizontal power structure and collaborative leadership.
\end{abstract}

Keywords: Policy Networks, Slum Settlements, Cities Without Slums

How to Cite: Hadi, A. Rusli, B. \& Alexandri, M.B. (2020). Policy Networks in the Implementation of 'Cities Without Slums' Program in Baleendah District, Bandung Regency. Jurnal Administrasi Publik (Public Administration Journal). 10(2): 138-146 


\section{INTRODUCTION}

Slum settlements or slum areas have become a problem in developing countries, especially countries with large populations such as in India, Brazil, Pakistan and including Indonesia. Efforts to eradicate slum settlements have received international attention so that many programs have been launched to eradicate slum areas such as the 11th Sustainable Development Goals (SDGs), namely cities and sustainable settlements with the target of ensuring access to decent, safe, affordable housing. and basic services, as well as arranging slum areas.

The 1945 Constitution states that "Everyone has the right to live in physical and spiritual prosperity, to have a place to live, and to have a good and healthy living environment and the right to obtain health services. Law Number 1 of 2011 concerning Housing and Settlement Areas has one of its scopes, namely the prevention and quality improvement of housing and slum settlements. It emphasizes that the state must prevent the emergence of new slum settlements and housing as well as improve the quality of settlements and slum housing.

Alleviating settlements and slum housing is a national development priority because it is included in the National LongTerm Development Plan (RPJPN) 20052025 and the 2015-2019 National MediumTerm Development Plan (RPJMN) which mandates the development and development of urban areas through handling the quality of the settlement environment, namely improving quality slum settlements, preventing the development of new slum settlements, and sustainable livelihoods.

The Ministry of Public Works and Public Housing, through Circular Number 40/SE /DC /2016, the Directorate General of Human Settlements, initiated the alleviation of slum settlements and housing through the Cities Without Slums (KOTAKU) program. The KOTAKU program supports local governments as the main actors in handling slum areas in realizing habitable settlements, including through the revitalization of the role of the Community Self-Help Agency (BKM). The KOTAKU program is a settlement and slum housing eradication program using a collaborative platform from the central, provincial, district / city governments, donors, the private sector, the community and other stakeholders, where the local government is the skipper in realizing livable settlements in their area.

Based on the Decree of the Regent of Bandung No. 663 / Kep.544 / 2014 concerning the Approval of the Determination of Slum Housing Areas and Slum Settlements in Bandung Regency, it is determined that slum housing and slum settlements in Bandung Regency cover a total of 30 areas in 13 Districts with a total area of 91.83 ha, details can be seen in the table below:

Table 1: Area of Slum Settlement in Bandung

\begin{tabular}{llll}
\multicolumn{3}{c}{ Regency } \\
\hline No. & sub-district & Category & Area (ha) \\
\hline 1 & Baleendah & High & 26.33 \\
2 & Bojongsoang & Moderate & 3.36 \\
3 & Cikancung & Moderate & 3.96 \\
4 & Still & Moderate & 3.68 \\
5 & Cileunyi & Moderate & 6.33 \\
6 & Majalaya & High & 3.54 \\
7 & Banjaran & Moderate & 2.36 \\
8 & Margahayu & Moderate & 6.03 \\
9 & Rancaekek & Moderate & 11.06 \\
10 & Cicalengka & Moderate & 5.09 \\
11 & Katapang & Moderate & 3.82 \\
12 & Afternoon & Moderate & 4.32 \\
13 & Dayeuhkolot & High & 11.95 \\
& total & & 91.83 \\
\hline
\end{tabular}

(Source: Decree of the Regent of Bandung Regency)

From the 11 Districts that have implemented the 'Cities Without Slums' program, Baleendah District is the area that has the largest slum area in Bandung Regency, namely 25.23ha with the high slum category and since the implementation of the Cities Without Slums' in 2017 to 2019, Balendah District is still the area with the largest slum area namely 9.87 ha only decreased by 12.16 ha since this program was implemented. 
There are several phenomena of problems implementing the Cities Without Slums' program in Baleendah District, Bandung Regency, namely:

1. This program supports the "100-0-100" action, namely 100 percent universal access to drinking water, zero percent to slum areas, and 100 percent access to proper sanitation and the target of zero percent for slum settlements by 2019 . However, since this program was rolled out in 2016 to 2019, the accomplishmentof the alleviation of slum settlements and slum housing in Bandung Regency has only reached 53.9 ha and there are still 28.88 ha of slum areas, especially in Baleendah District, which is still the most slum sub-district in Bandung Regency with the remaining 9.87 ha.

2. The low level of community participation and poor coordination so that the implementation of Cities Without Slums is ineffective. This passive attitude of the community also has an impact on completed construction projects such as community participation and responsibility in the maintenance and maintenance of facilities and infrastructure that have been built.

3. One of the objectives of the Cities Without Slums' program is the formation of a Housing and Settlement Area Working Group (Pokja PKP) at the district / city level in handling wellfunctioning slum settlements, but in its implementation Pokja PKP Bandung Regency has not been running effectively due to lack of support from the ProvincesGovernment, the private sector as housing developers in terms of supporting the handling of slum areas as well as structural overlaps that are considered independent, such as Pokja AMPL and PokjaSanitasi which have not been integrated into Pokja PKP.

4. As a collaborative program involving various stakeholders, Bandung Regency has not involved universities and the mass media where there has been no collaboration between the Bandung Regency government, mass media and universities so that there is a lack of support in implementing a city without slums in Bandung Regency.

Based on the background description of the research shows that the KOTAKU program in Baleendah District still has several problems in the implementation process, both at the implementing level and at the community level. In implementing collaborative programs, it must emphasize the interaction of related actors as expressed by(Nugroho, 2012)the policy implementation process is a complex of interaction process between a large number of actors in a network of independent actors, it is the interaction between actors in the network that will determine how implementation should be carried out, issues that must be addressed. and the expected discretions to be an important part of it.

Seeing the various problems in implementation faced by Baleendah District, Bandung Regency, especially in the implementation of KOTAKU, it is necessary to formulate a more appropriate public policy management so that the objectives of the City Without Slums can be felt by the community.

Research related to cities without slums conducted by Yuliani \& Rosyida (2017) Collaboration in implementing Cities Without Slums in SemanggiKelurahan, Surakarta City has not been going well because only a few stakeholders are involved and communication between stakeholders is not communicative.

Christianingrum \& Djumiarti (2019)states the implementation of the Cities Without Slums' program in East Semarang District succeeded in reducing the area of slum settlements but there are still problems where there is still a lack of community participation due to the lack of 
socialization from the government regarding the existence of a city program without slums.

Sari (2018)stated that the implementation of the 'Cities Without Slums' in Bligo Village runs effectively because there is good participation from the society through ideas, job security, and money. However, the implementation in Jiken Village is a village that fails to implement the 'Cities Without Slums' because the implementation is limited to physical development which is dominated by the role of the government without community participation.

Based on previous research that has been described above, it can be concluded that the implementation of Cities Without Slums has problems in stakeholder involvement and society participation which has not been effective, this is in contrast to the Slumless City program platform which is a collaborative program between related actors.

Seeing the importance of the problems in implementing the KOTAKU policy network in Bandung Regency, researchers are interested in conducting research on the Policy Network in the Implementation of the KOTAKU Program in Baleendah District, Bandung Regency.

\section{RESEARCH METHODS}

This research is a type of qualitative research with descriptive methods to describe, analyze and identify how the policy network in implementing city programs without slums in Baleendah District, Bandung Regency. Types and sources of data used consisted of primary data obtained directly in the field through observations and interviews with informants determined by purposive sampling technique, namely the Head of the Public Housing, Settlement and Land Services Office of Bandung Regency, Pokja PKP Bandung Regency, Head of Baleendah District, Head of Village and Agency. Selfreliance of the Baleendah, BojongMalaka and Andir communities. Secondary data were obtained from statutory regulations, literature, documents, reports and archives relating to cities without slums. For analyzing the data, it used interactive model which consists of data collection, data condensation, data display and conclusion (Miles, Huberman, \& Saldana, 2013).

\section{RESULTS AND DISCUSSION \\ Policy Network in Implementation KOTAKU in Baleendah District, Bandung Regency}

Klijn \& Koppenjan (2000) observed that the use of network concepts in policy science dates back to the early 1970 s. They argued that in policy implementation studies, especially in the "bottom-up" approach as a resistance to the "top-down" approach. This concept was used to map inter-organizational relationships and to assess the influence of these patterns on the policy process.

There were some understanding of policy networks, depending on what context they come from, as suggested by (Raab \& Kenis, 2009). Policy networks are groups of organizations that are linked because of dependence on resources and formed by more than two organizations that are interconnected to achieve common goals. Policy networks can generally be understood as structural elements of a collaborative network that document components such as reciprocity, equity and representation (P. deLeon, 2009).

Policy network by Rhodes (1997) more showed the variety of interactions between government, private sector, society and international actors in a policy arena. Enroth (2011) then emphasized the different things. It is not just a pattern of communication or interaction between actors who are linked in different and independent structures. The policy network essentially contains the natural conditions of the strategy to act in an institutional context which includes the 
sharpening of perceptions, considerations and interactions of policy actors. Meanwhile Suwitri (2011) stated the policy network is a relationship of interdependence among policy-making actors. It is further stated that a modern organization and a new public management, needs a policy network that absolutely facilitates the formulation of every policy. It is useful for smoothing the implementation of public policies and at the same time evaluating whether the policies that have been established are in accordance with the public interest.

The government did not only rely on its internal capacity in implementing a policy and implementing a program. Limited capabilities, resources and networks that are a supporting factor for the implementation of a program or policy, encourage the government to collaborate with various parties, both with the government, private parties and the community and civil society (Subarsono,2016).

This was due to limited capabilities, resources and networks which are the determining factors in implementing a program or policy. The government could collaborate with various parties, both with fellow governments from central to regional, private and public, civil society communities so as to create networks in achieving policy or program objectives.
DeLeon and Varda (2009) introduced the theory of collaborative policy networks. This model explains that the 7 characteristics to create an optimal policy network in achieving the objectives of a policy or program consist of representation, reciprocity, horizontal power structure, embeddedness, trust and formality, participatory decision making, and collaborative leadership.

More details regarding the discussion of policy networks in implementing KOTAKU in Baleendah District, Bandung Regency are as follows:

\section{Representation / Diversity}

The virtue of policy networking is the diversity of stakeholders involved so that there is an exchange of resources and information needed to create a common goal, this is in accordance with Hajer and Wagenaar's (2003) opinion who stated that diversity will add values in any public policy process.

The implementation of KOTAKU program in Baleendah District cannot be carried out only with the role of the Bandung Regency government, but there must be collaboration or togetherness of all interested parties, whether from the government, private sector, society, universities, and the mass media. In fact, the Bandung Regency government only involves two actors from the government and society, which can be seen in table 2 :

Table 2 Kotaku Actors, Baleendah District

\begin{tabular}{|c|c|c|c|c|}
\hline Government & Public & Academics & Private & Media \\
\hline Ministry of PUPR & BKM Rasa & - & - & - \\
\hline West Java province & BKM KaryaEndahMandiri & - & - & - \\
\hline Disperkimtan Bandung Regency & BKM AmanahUmmah & - & - & - \\
\hline $\begin{array}{l}\text { Andir, Baleendah, and BojongMalaka } \\
\text { villages }\end{array}$ & $\begin{array}{l}\text { The people of Andir, Baleendah, } \\
\text { and BojongMalaka }\end{array}$ & - & - & - \\
\hline
\end{tabular}

Source: Researcher Processed Data, 2020

The lack of diversity in implementing actors in KOTAKU in Baleendah sub-district was due to poor coordination and the absence of a grand design or slum management planning in Baleendah District, the grand design of slum handling is needed to mobilize every actor with an interest simultaneously, both from the government and private, the universities, the society and the mass media. The diversity of KOTAKU implementers in Baleendah District is a force that unites 
various resources to achieve zero percent of slum settlements in Baleendah District.

\section{Reciprocity}

Reciprocity or reciprocal relationship is the exchange of resources in a policy network, either in the form of financial resources or human resources. Rhodes (1997) argued that reciprocal relationships are motivated by the exchange of resources because an organization requires other organizational resources in order to achieve goals.

For the aspect of human resources in terms of quantity and quality has been sufficient. BKM Rasa, EndahMandiri, and AmanahUmmah as implementers in the field have understood their duties and authorities in implementing Slumless City and they are also accompanied by Korkot and Faskel which provide technical assistance, but on the community side there is still low awareness of caring for the environment in which they live they such as littering.

In terms of financial sources, the CitiesWithout Slums program originates from the APBN because it is a Central Government program called BDI or Investment Fund Assistance. For the Baleendah District from 2017 to 2019, a total of Rp. 5.5 billion with the following details:

Table 3 Investment Assistance Fund for Kotaku, Baleendah District (000)

\begin{tabular}{lll}
\hline No. & Village & Total \\
\hline 1 & Baleendah & $2,350,000$ \\
2 & Andir & $1,500,000$ \\
3 & Bojong Malacca & $1,650,000$ \\
\hline \multicolumn{2}{l}{ Total } & $5,500,000$ \\
& Source: & Researcher Processed Data, 2020
\end{tabular}

However, apart from relying on BDI, as a collaborative program, the society also participated by donating through community self-help, such as making concrete rebates and toilets in RT 06 and 07 RW 09, Baleendah village community, providing Rp. 2,372,760 and the community donated their land for the construction of green open spaces at RT 03 RW 13 Andir Village.

\section{Horizontal Power Structure}

Collaborative policy implementation would be more effective if it was not hierarchical. The Cities Without Slums program is "bottom-up" because the society is the implementer and the government is only the coordinator. The structure in the policy network for implementing cities without slums in Baleendah District included several characteristics, namely participatory, hierarchical and consultative, as shown in table 4:

Table 4 Structure Properties of KOTAKU

\begin{tabular}{ll}
\hline Actor & Government \\
\hline Government & Hierarchical \\
Public & Hierarchical and \\
& Consultative \\
Community Groups & Consultative Hierarchy \\
\hline \multicolumn{2}{c}{ Source: Researcher Processed Data, 2020 }
\end{tabular}

Based on table 4, the implementation of cities without slums in Baleendah District, there was still a hierarchical structure, there was also a consultative and participatory pattern. This hierarchical pattern is a form of implementing responsibility on the part of Bandung Regency Government which emphasizes participation and consultation, such as the Bandung Regency Government can 
coordinate BKM to implement KOTAKU and also consult BKM and the community regarding indicators of basic services needed in areas designated as slum. However, the organizational structure that has been formed in the guidelines for implementing cities without slums has not been running properly due to the absence of involvement of the Baleendah District as the coordinating party at the sub-district level.

\section{Embeddness}

Embeddness is needed in the policy network to create good interaction or communication (Dimaggio \& Zukin, 1990). argues that there are several categories that cause embeddedness, namely due to structural, cognitive, cultural, and political ties.

From a structural perspective, the Bandung Regency Government was the skipper to lead the implementation of slum removalin collaboration with various stakeholders from government to society. The embeddness of city executing actors without slums in Baleendah District was formed because of the existence of an organizational structure that made implementing actors collaborate and coordinate with each other. The Public Settlement Service, Housing and Land Areas were a work unit assisted by the municipal government to supervise BKM in the implementation of Cities without Slums activities.

\section{Trust and Formality}

Policy networks will not achieve their goals without trust and formality among stakeholders who are not only present at the policy formulation stage but must be present in every public policy process.

To create trust in the Public Housing, Housing and Land Service of Bandung Regency as a technical service or working unit, it was very active to supervise the implementation of this field because the service was only the party that distributes
Investment Assistance Funds to BKM and BKM which used the funds, although only as the party that distributed funds, the Department of Public Housing, Housing and Land of Bandung Regency still made an accountability report which will be examined by the Financial and Development Supervisory Agency or BPKP. Whereas BKM in Baleendah District as recipients of Investment Assistance Funds and implementing Cities without Slums program also strived for openness to increase public confidence in BKM in carrying out the infrastructure development activities BKM must make implementation accountability reports, even BKM Andir Village has the initiative to invite NGOs and mass media to supervise and cover their activities even though there was no formality between BKM and the mass media and BKM also displayed information on sources of funds for KOTAKU activities. Even BKM Andir Village had the initiative to invite NGOs and mass media to supervise and cover their activities even though there was no formality between BKM and the mass media and BKM also displayed information on the source of funds for KOTAKU activities.

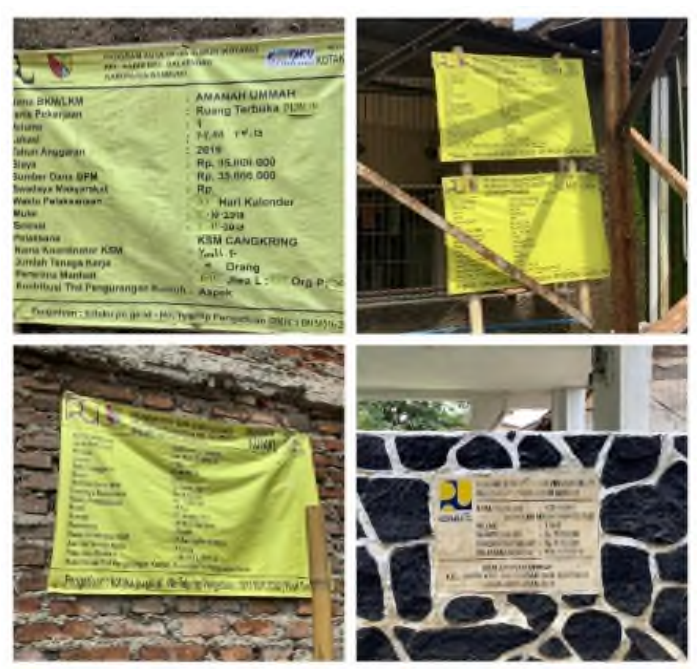

Figure 1 Activity Information Source: Researcher, 2020 


\section{Participatory Decision Making}

Participation in decision making is a concept of democratic decision-making, The decision-making process must represent all the interests and needs of existing policy makers. In the good governance approach, society participation was not only carried out at the implementation or implementation stage but started from the decision-making stage, policy implementation and policy evaluation.

Kotaku was a national program implemented by the society through the Community Self-Reliance Agency, the district government was not involved in formulating Cities without Slums program and did not intervene in decisions taken by BKM as representatives of the society in Bandung Regency government approved the RPLP or Settlement Environmental Management Plan which the formulation is in the society, but Bandung Regency Government facilitated BKM with a technical team. Likewise, the BKM in Baleendah District, before making the RPLP, BKM held deliberations with the society regarding what infrastructure the society needed and the society's suggestions were discussed with the consultant team.

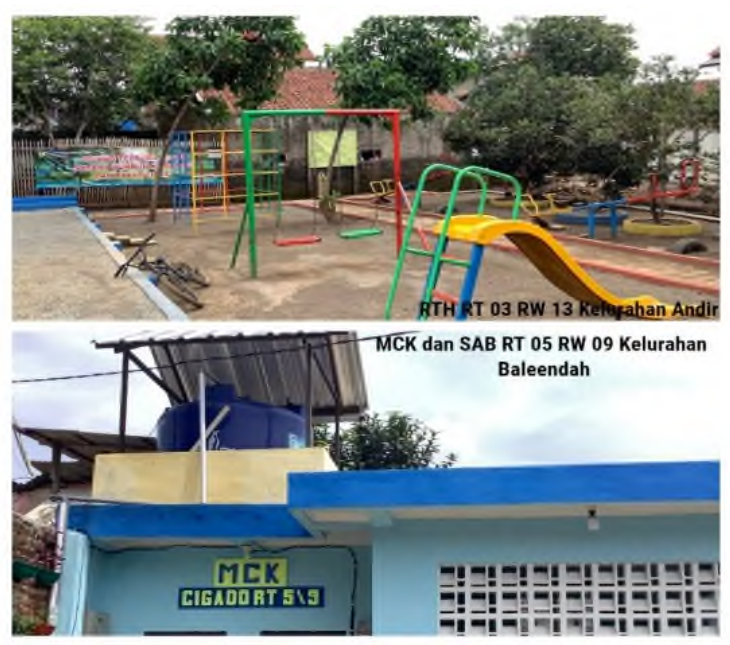

Figure 2 My City Activities

Source: Researcher, 2020

\section{Collabortive Leadership}

The success of the implementation of the Cities without Slums program in Baleendah District can be seen from the leadership's ability to coordinate each stakeholder involved in order to create collaboration in a policy network. The leader's ability to collaborate with stakeholders is one of the keys so that the objectives of the Cities without Slums program can be achieved, because a leader can coordinate how the policy network works in implementing cities without slums in Baleendah District.

Based on the characteristics of Collabortive Leadership, the Head of the Public Housing, Housing and Land Office of Bandung Regency as the skipper and person who is responsible with KOTAKU program in Bandung Regency was still not optimal in coordinating stakeholders. The ability to coordinate district government to sub-district, community, BKM, technical team has been running well from before to the time of implementation. However, it has not been able to coordinate other stakeholders such as the private sector, universities, and the mass media even though this program has a collaborative platform that emphasizes the involvement of stakeholders because housing problems in residential areas will not only be able to rely solely on the ability of the government and the society but also collaboration with the private sector, the universities, and mass media. It is also explained in guidelines of Cities without Slums program.

\section{CONCLUSION}

Based on the analysis, there were seven characteristics that determined the policy network in implementing the Cities without Slums program in Baleendah District, Bandung Regency, namely: representation, reciprocity, horizontal power structure, embeddedness, trust and formality, participatory decision making, and collaborative leadership. The policy network in implementing the KOTAKU 
program in Baleendah District, Bandung Regency had not run optimally because theoretically, the policy network is formed of more than two actors who are interconnected to achieve goals and as stated by Deleon and Varda that these 7 characteristics must be exist and be integrated.

\section{BIBLIOGRAPHY}

Christianingrum, S., \& Djumiarti, T. (2019). Implementasi Program Kota Tanpa Kumuh Di Kecamatan Semarang Timur. Journal of Public Policy And Management Review, 8.

Dimaggio, P. ., \& Zukin, S. (1990). Structures of Capital: The Social Organization of Economic Life. New York: Cambridge University Press.

Enroth, H. (2011). Policy network theory. https://doi.org/10.4135/9781446200964.n 2

Hajer, M,A.and Wagenaar, H., eds. (2003). Deliberative Policy Analysis: Understanding Governance in the Network Society. New York: Cambridge University Press.

Klijn, E. H., \& Koppenjan, J. F. M. (2000). Public Management and Policy Networks. Public Management: An International Journal of Research and Theory, 2(2), 135-158. https://doi.org/10.1080/147190300000000 07

Miles, M. B., Huberman, A. M., \& Saldana, J. (2013). Qualitative Data Analysis, A Methods Sourcebook (3 Edtion). SAGE Publications.
Nugroho, R. (2012). Public Policy. Jakarta: PT Elek Media Kompotindo.

P. deLeon, D. M. V. (2009). Toward a Theory of Collaborative Policy Networks: Identifying Structural Tendencies. The Policy Studies Journal, 37(1), 59-74.

Permata Sari, A. C. (2018). Analisis Implementasi Pembangunan Partisipatif dalam Program Kota Tanpa Kumuh ( KOTAKU ) Studi Komparatif : Desa Bligo Kecamatan Candi dan Desa Jiken, Kecamatan Tulangan, Kabupaten Sidoarjo, Jawa Timur. Equilibrium: Jurnal Ekonomi-Manajemen-Akuntansi, 14(2), 57. https://doi.org/10.30742/equilibrium.v14i2 .452

Raab, J., \& Kenis, P. (2009). Heading toward a society of networks: Empirical developments and theoretical challenges. Journal of Management Inquiry, 18(3), 198-210. https://doi.org/10.1177/105649260933749 3

Rhodes, R. A. W. (1997). Understanding Governance: Policy Networks, Governance, Reflexivity and Accountability.

Subarsono, A. (2016). Kebijakan Publik dan Pemerintahan Kolaboratif Isu Isu Kontemporer. Yogyakarta: CV. Gava Media.

Suwitri, S. (2011). Jejaring Kebijakan dalam Perumusan Kebijakan Publik. Semarang: Badan Penerbit Universitas Diponegoro.

Yuliani, S., \& Rosyida, G. P. D. (2017). Kolaborasi dalam Perencanaan Program Kota Tanpa Kumuh (KOTAKU) di Kelurahan Semanggi Kota Surakarta. Jurnal Wacana Publik, 1(2), 33-47. 